\title{
QUENTIN SKINNER
}

Hobbes and Republican Liberty

Cambridge University Press, Cambridge 2008, ss. 270

MARCIN POLAKOWSKI

Wydział Humanistyczny UMK

\section{Hobbesa zmagania z wolnością}

Q uentin Skinner należy do czołowych współczesnych historyków myśli politycznej. Niegdysiejszy profesor Uniwersytetu w Cambridge, a od niedawna wykładowca Queen Mary, University of London, swym dorobkiem intelektualnym wydaje się promować cnoty nie zawsze osiągalne dla akademików parających się tą trudną dziedziną naukową. Skinner bowiem w swej bogatej twórczości spaja imponującą wiedzę i niezwykle szczegółowe analizy historyczne z przystępnością języka i zaskakującą niekiedy konkluzywnością swej argumentacji. Jest to postawa tym bardziej interesująca, że należy on do nurtu tych przedstawicieli historii myśli politycznej, którzy bronią się przed filozoficzną nadinterpretacją dzieł dawnych autorów traktatów politycznych. W swych pracach stara się więc analizować i oceniać ich dorobek przede wszystkim w historycznym kontekście, w którym przyszło im wzrastać i tworzyć. Jednocześnie jednak nie ulega pokusie bezprzedmiotowości lub kronikarstwa, na którą mógłby wydawać się narażony, lecz stara się, by jego szczegółowe badania były jednocześnie znaczącym głosem we współczesnych debatach o istocie, roli czy kształcie polityki.

Ostatnia książka Skinnera Hobbes and Republican Liberty, będąca owocem gościnnych wykładów wygłoszonych w Oksfordzie i wydana nakładem wydawnictwa uniwersyteckiego z Cambridge, w dużym stopniu skupia i kontynuuje główne zainteresowania jej autora. Stanowi ona bowiem zarówno kontynuację licznych studiów dotyczących myśli Thomasa Hobbesa, jakie angielski autor prowadził wcześniej choćby w Reason and Rhetoric in the Philosophy of Hobbes (1996) czy Visions of Politics, Volume III: Hobbes and Civil Science (2002), jak i rozważań dotyczących teoretycznych podstaw tzw. przełomu nowożytnego, uskutecznianych przykładowo w dwóch częściach zbiorowej 
pracy The Foundations of Modern Political Thought. Wreszcie jest ona bezpośrednią kontynuacją rozważań, dotyczących losów republikańskiej teorii życia publicznego i wolności, które zostały podjęte w Liberty before Liberalism (1998).

Omawiana książka Skinnera składa się z sześciu rozdziałów. Autor opisuje w nich intelektualne źródła Hobbesowskiego rozumienia świata, rozwój pojmowania pojęcia wolności w kolejnych jego dziełach: Elementach prawa (temu traktatowi Hobbesa autor poświęca dwa rozdziały) 0 obywatelu i Lewiatanie oraz następstwa jego teorii wolności dla rozumienia problemu politycznych zobowiązań obywateli. Wszakże przez całą książkę, w podzielonych na rozdziały rozważaniach, dających uszeregować się historycznie w zgodzie z kolejami życia Hobbesa, przewija się fundamentalny wątek losów republikańskiej teorii wolności oraz wpływu, jaki wywarła ona na rozwój argumentacji autora Lewiatana.

Republikańska teoria wolności miała posiadać dominującą pozycję w Anglii w okresie życia „filozofa z Malmesbury”. W odróżnieniu od rozumienia wolności, proponowanego przez Hobbesa rozróżnia ona stan wolności i niewoli na podstawie faktu bycia we władzy kogoś innego. Innymi słowy stan niewoli to niemoc rozporządzania samym sobą, stan bycia niewolnikiem. „Utrata wolności poniesiona przez niewolnika wynika z życia «pod władzą pana» oraz podporządkowania jego wyborom (arbitrium) czy arbitralnej woli” (s. IX). Trzonem republikańskiej teorii wolności jest wobec tego obrona przed ustanowieniem arbitralnej władzy, gdyż to ona degraduje wolnych członków społeczności do statusu niewolników. Nie tylko działanie tego typu władzy, lecz nawet samo jej istnienie jest zagrożeniem dla ludzkiej wolności. By odebrać człowiekowi wolność nie trzeba jakichkolwiek działań, wystarczy sama obecność i świadomość podległości arbitralnej władzy. Zniewolenie niewolnika nie zawsze jest efektem bezpośredniej ingerencji i ograniczenia narzuconego przez jego pana. W istocie wystarczy świadomość podporządkowania jego poleceniom, by niewolnik starał się działać w zgodzie z jego wolą. Skinner odwołując się do klasycznej wersji republikańskiej teorii wolności wyłożonej przez Jamesa Harringtona, konstatuje więc, że „niedola niewolników polega na tym, że nie kontrolują oni swego życia i są nieustannie zmuszeni żyć w stanie nieustannego lęku przed tym, co może, lecz nie musi się z nimi stać" (s. XII).

Tezą Skinnera jest twierdzenie, że to właśnie republikańska teoria wolności, prezentowana $\mathrm{w}$ traktatach filozoficznych i politycznych, jak i mowach parlamentarnych, tworzy główny punkt odniesienia dla Hobbesa wypracowującego własną, konkurencyjną koncepcję wolności w XVIIwiecznej Anglii. Teoria republikańska miała bowiem, przed wybuchem woj- 
ny domowej w 1642 roku, uzyskać dominującą pozycję wśród oponentów monarchii Stuartów. Hobbes zaś, przerażony efektami chaosu, o który obwiniał przeciwników króla, miał z kolei wypracować w sposób bardziej systematyczny niż ktokolwiek inny teorię władzy absolutnej, wrogiej republikańskiej definicji wolności.

Wystąpienie Hobbesa i dyskredytacja tejże koncepcji stanowi zdaniem Skinnera „przełomowy moment w historii anglojęzycznej myśli politycznej” (s. XIII). Choć teoria wolności Hobbesa była już wielokroć omawiana w literaturze naukowej, to autor Hobbes and Republican Liberty przekonuje, że warto się jej przyjrzeć ponownie z kilku powodów. Przede wszystkim nie doczekała się ona jak dotąd rzeczowej analizy swego rozwoju w kolejnych pismach Hobbesa, niestanowiących wszakże monolitu, lecz przedstawiających w istocie cztery, przynajmniej w szczegółach odmienne wersje jego filozofii politycznej (czwarta wersja jego teorii, prócz tych przedstawionych w Elementach prawa, 0 obywatelu i Lewiatanie miała zostać opracowana w historycznie najpóźniejszej łacińskiej wersji tego ostatniego dzieła). Hobbesowskie pojmowanie wolności nie spotkało się również z analizą, poświęcającą należytą uwagę historycznym okolicznościom i czynnikom, w jakich było ono rozwijane. Przedstawienie zatem historyczno-politycznego kontekstu, w jakim wizja wolności Hobbesa powstawała, czyli właśnie ukontekstowienie teorii oraz prezentacja modyfikacji dokonywanych w kolejnych jego pismach są głównymi celami autora recenzowanej książki.

W pisanych w roku 1640 Elementach prawa Hobbes nie posiada jeszcze dostatecznie rozwiniętej koncepcji wolności. Mimo że stanowi ona ważny punkt argumentacji, jego głównym celem jest ukazanie "despotyzmu jako prawowitej formy monarchii” oraz „zrehabilitowanie władzy absolutnej” (s. 52). Nie formułując zatem jednoznacznej definicji, identyfikuje on wolność ze stanem możności użycia naszych naturalnych władz i zdolności oraz samodecydowania o sobie na gruncie własnej woli (s. 35). W ten sposób Hobbes przekonuje, że wolność występująca w stanie natury nie jest właściwa dla nienaturalnej kondycji podporządkowania władzy. Władza, której Hobbes broni, stoi zatem w sprzeczności z wolnością zawsze i bez względu na to, jakiej formie rządu podlegamy. Będąc poddanymi danego suwerena, tracimy część lub całość - Hobbes tutaj nie jest konsekwentny - naturalnej wolności i jest to niewielka cena, którą musimy zapłacić w imię dążenia do pokoju i wyzwolenia nas z dużo bardziej uciążliwego strachu w stanie natury.

Zgoła odmienną koncepcję wolności przedstawia Hobbes w 0 obywatelu napisanym w 1642 roku. Zdaniem Skinnera, wolność rozumiana podobnie jak już we współczesnych definicjach wolności negatywnej, zostaje tutaj określona jako brak przeszkód w działaniu, który nie ulega zniszczeniu w ramach 
podległości suwerennej władzy. W ramach obrony władzy absolutnej i polemiki z pisarzami, właśnie $\mathrm{w}$ imię wolności dyskredytującymi nadużywanie praw przez monarchię, Hobbes stara się przekonać czytelnika, iż owa wolność w ramach podległości władzy w żaden sposób nie może być utożsamiona z niewolą, zaś obywatel nigdy z zasady nie może stać się niewolnikiem. Choć oczywiście naturalna wolność ludzi w ramach poddania władzy zostaje w dużej mierze ograniczona przez jej rozkazy w celu zachowania nas od wojny wszystkich ze wszystkimi, to jej strata nie może być w żadnej mierze porównana do popadnięcia w stan niewolnictwa. Ten, kto podlega znanej mu władzy i jej nakazom, nie jest według Hobbesa ciemiężony, lecz rządzony, a wręcz poddawany krzepiącemu kierownictwu (s. 121-122). Taką argumentację umożliwia właśnie zmieniona i doprecyzowana koncepcja wolności podyktowana według Skinnera przede wszystkim krytyką władzy królewskiej, opartej na obronie instytucji wolności, która przybierała na sile w Anglii początku lat 40. XVII wieku.

Definicja wolności zapronowana w 0 obywatelu, zostaje przez Hobbesa poprawiona w jego najsłynniejszej pracy - Lewiatanie (1651), w której wolność jest już nie tylko zwyczajnym brakiem ograniczeń w działaniu, lecz brakiem ograniczeń zewnętrznych (s. 127). Jeśli wcześniej naszą wolność ograniczały przeszkody absolutnie krępujące naszą wolę, o tyle teraz jedyną formą niewoli jest fizyczne pozbawienie nas możliwości działania (s. 128). Odtąd nawet strach przed gwałtowną śmiercią, ograniczający działania człowieka i będący głównym czynnikiem ustanowienia i poddania się władzy państwowej, nie umniejsza naszej wolności. Zdaniem Skinnera propozycja ta jest kamieniem milowym w nowożytnej teorii wolności, gdyż - sformułowana w odpowiedzi zwolenników teorii republikańskiej - w sposób uniwersalny neguje wizję wolności jako braku zależności.

Skinner powiada wprost, że Hobbesowskie rozważania na temat wolności wywarły przemożny wpływ nie tylko na współczesne mu dyskusje o polityce, lecz na całą późniejszą myśl polityczną. Wątpliwą, według Skinnera, zasługą Hobbesa było więc nie tylko zdeprecjonowanie republikańskiej koncepcji wolności, lecz także zapoczątkowanie tradycji rozważań o wolności w idiomie wolności negatywnej, tak bardzo rozpowszechnionym zarówno w teorii, jak i praktyce współczesnego państwa. Było to zjawisko o tyle niekorzystne, że zanegowało alternatywne dla dychotomii wolności pozytywnej i negatywnej rozumienie tej wartości. Skinner jednak w Hobbes and Republican Liberty nie tyle rehabilituje republikańską teorię wolności czy refutuje alternatywne rozważania Hobbesa, lecz raczej poprzez uważne historyczne ich ukontekstowienie stara się uzmysłowić czytelnikowi, iż sformułowanie negatywnej teorii wolności wynikało przynajmniej w pewnej mierze z historycz- 
nych okoliczności, w których Hobbes żył i pisał. Tym samym stara się raczej zanegować rzekomą bezalternatywność również współczesnych rozważań o wolności, aniżeli proponować konkretne rozwiązania w tej kwestii. W ten sposób usiłuje bronić się z jednej strony przed zarzutem ahistoryczności swoich rozważań, w jaką mógłby popaść, samemu beztrosko przenosząc pewne koncepcje na współczesny grunt, $\mathrm{z}$ drugiej zaś przed antykwarycznością i bezpredmiotowością analiz, które rozwija. Wypada się więc zgodzić, że jeśli staraniem Skinnera było - jak sam pisze w końcowych słowach swej książki - nie tylko „przedstawienie Hobbesowskiego ataku na republikańską teorię wolności", którym - biorąc pod uwagę zwłaszcza jego historyczny wpływ - „zwyciężył w bitwie”, lecz również „ciągle warte podjęcia zapytanie, czy odniósł on zwycięstwo także w samym sporze" (s. 216), to cel ten został z nawiązką wypełniony.

Napisana - co warto odnotować - elegancką, lecz przystępną angielszczyzną niezwykle erudycyjna książka Skinnera wydaje się niezwykle ważną pracą zarówno w dorobku tego pisarza, jak i w badaniach spuścizny Hobbesa. Jej wartością jest nie tylko, trudna tutaj do ocenienia, choć przekonująca historyczna praca, jaką wykonał, lecz przede wszystkim wkład, jaki wnosi ona do zupełnie współczesnych dyskusji dotyczących teorii i praktyki politycznej. Jest to wszakże opowieść przede wszystkim o losach wolności, a więc jednego z najważniejszych pojęć, którego określone pojmowanie wyznacza konkretne rozumienie polityki, jak również tożsamość współczesnych społeczeństw. Warto więc oczekiwać polskiego tłumaczenia Hobbes and Republican Liberty, gdyż jest to praca, która mogłaby wnieść bardzo wiele do polskojęzycznej literatury, podejmującej tematykę teoretycznego i historycznego statusu wolności, jak i niezwykle ubogiego zasobu prac mówiących o filozofii politycznej Thomasa Hobbesa. 